\title{
How Farmers Make Investment Decisions: Evidence from a Farmer Survey in China
}

\author{
Shuangjin Wang ${ }^{1}$, Yuan Tian ${ }^{2, * \mathbb{D}}$, Xiaowei Liu $^{3}$ and Maggie Foley ${ }^{4}$ \\ 1 School of Management, Tianjin University of Commerce, Tianjin 300134, China; dualwang@tjcu.edu.cn \\ 2 School of Economics and Management, Beijing Jiaotong University, Beijing 100044, China \\ 3 College of Business, St. Ambrose University, Davenport, IA 52803, USA; LiuXiaowei@sau.edu \\ 4 Davis Business School, Jacksonville University, Jacksonville, FL 32211, USA; mfoley3@ju.edu \\ * Correspondence: tianyuanty@bjtu.edu.cn
}

Received: 19 November 2019; Accepted: 25 December 2019; Published: 27 December 2019

\begin{abstract}
Based on the grain production data hand collected in Mid-East China, a multinomial Logit model was employed to analyze factors that are critical to farmers' investment decisions in food production. Reasonable explanations are provided to help understand differences between expected farmers' investments in grain production and the actual results. It was found that the cost of machinery and the number of farmers is key factors affecting farmers' willingness to adjust investment. Further research shows that most of the farmers who had the willingness to adjust investment did not implement the adjustments in the short-term. From the micro-adaptability expectation perspective, the time that it takes to adjust the planting area could explain farmers' investment adjustment intention and the behavior. From the macro-investment perspective, short-term output elasticity of physical capital is less than long-term output elasticity. The differences between farmers' willingness to invest and the actual results are therefore generated. These findings suggest that it is necessary to strengthen the application of big data technology in agriculture in order to improve the platforms' efficiency in data releasing and reaching out to farmers to provide more accurate advice regarding investment adjustment.
\end{abstract}

Keywords: grain farmers; willingness to adjust investment; multinomial Logit model

\section{Introduction}

In the process of coordinated development of agriculture in the Mid-East region of China, the level of agricultural collaborative innovation is relatively low. In the aspects of transformation of agricultural technology achievements and sharing of agricultural technology resources, there are still many inter-regional inconsistencies [1], and the synergistic effect of innovation is not strong. These problems are reflected in farmers' technology choices. It is difficult to match the agricultural technology services with the technical needs of the farmers effectively, which is reflected in the farmers' relatively blind choice and adjustment behavior in grain production investment. Due to the differences in natural resource endowments, economic and social foundations, scale of operations, and farmers' conditions, the farmers' investment adjustment behavior varies significantly [2-4].

The Mid-East area of China has a high level of opening-up and a more developed economy. Compared with other industries, agricultural output value accounts for a small proportion in this area, and the land resources are insufficient to meet the needs of the population [5]. Under the background of the development of urban agriculture, the grain planting area in this region is decreasing year by year. Due to the relatively low income from farming, a large number of young people find non-agricultural jobs in cities, which would cause a lack of labor force in agriculture in the future [6]. Therefore, it is significant to expand scale of the planting area, improving income from grain production in this area. 
In the farmers' investment adjustment behavior, technology choice is an essential factor. Technologies play an increasingly important role in grain production [7-9]. Undoubtedly, to improve the contribution rate of technologies, it is not enough to only strengthen the research and development capabilities of scientific personnel, but more importantly, the adoption of agricultural technologies by farmers is the main factor affecting the adjustment of grain-growing investment [9]. In this paper, we define the grain-growing investment as the production costs and land costs measured in monetary terms. The production costs include material, service, and labor costs. From the perspective of this research, the farmers' willingness to adjust grain-growing investment is affected by various factors. Meanwhile, there are significant differences between the willingness and actual behavior, and the reasons for the differences are key issues that are discussed in this paper.

A variety of research methods were used in previous research to study farmers' investment adjustment behavior from different perspectives. For example, Factor Analysis [3,7], Multinomial Logit Model [8,10,11], Deterministic Discrete Event Model [9], Mixed Logit Model with Flexible Mixing Distribution [12], Tobit Model [13,14], Probit Model [15-17], and Structural Equation Modeling [18,19].

It is widely accepted that farmers' investment adjustment behavior is affected by many factors, but different literature has different opinions on key influencing factors that affect farmers' investment behavior. Adimassu et al. [20] have found that farmers' investments are limited by their capabilities. Okello et al. [21] have revealed that economic benefits, such as higher yields and income, can affect farmers' investment in seed selection. Also, the cropped area, scale of the farmland, and agricultural income significantly influence farmers' willingness to invest [10]. The government's support and favorable policies can positively promote the agriculture investment of farmers [22,23]. Adimassu et al. [2] finds that farmers' investment behavior is affected by five major factors: households' resource endowments, knowledge, and experience of farming, access to information, social capital, and availability of family labor.

Moreover, some economic studies focus on specific factors that affect investment choice, such as state subsidies [24], the impact of agricultural cooperatives [25], risk preferences [26,27], the mode of communal land acquisition [28], government policies [29], and the presence of a price floor [13]. Besides, Ullah and Anad [30] examine the factors that influence the level of agricultural mechanization: economic condition of farmers, the land tenure system, scale of farmland, cost of fuel, and the cost of renting agricultural machinery. Konrad et al. [15] have found that the scale of farm operations, environmental concerns, and innovation readiness are important for farmers' technology investments.

Factors such as the effect of planting structure adjustment and the output elasticity of capital can affect the investment adjustment behavior of farmers, and have been investigated by some studies. Ji et al. [31] have found that the shortage of a labor force can be supplemented by increasing capital input. In addition, other reasons may also lead to investment adjustment behavior such as attitudes toward capital input [4], the amount of agricultural income [32], expected financial benefits from capital input [33], and differences in adjustment capabilities [34].

Many studies have investigated farmers' willingness to adjust investment and their actual behavior based on both the theoretical and the empirical studies; however, further exploration is needed due to the following reasons. Firstly, current literature mainly studies the factors influencing farmers' willingness to adjust investment from the perspectives of government and the market [12,35], and mainly uses macroeconomic statistics. To the best of our knowledge, no prior work has explored Chinese farmers' investment choice behavior, especially in the Mid-East area of China, from the perspective of farm household characteristics and their attitudes. Secondly, the differences between the farmers' willingness and behavior are probably caused by certain constraints, such as investment capabilities and the substitution effect of input factors [36,37]. However, current literature rarely investigates the association between capital and labor input that can influence investment adjustment behavior.

This paper contributes to the current literature in the following two aspects. Firstly, this paper employs the Multinomial Logit Model to analyze the odds of increasing/decreasing investment, and comparing the odds of keeping investments unchanged using three types of variables: capital 
input, labor input and attitudes, and characteristics of farm households. Based on the survey data, this paper investigates the factors influencing farmers' willingness to adjust investment in the Mid-East area of China. Secondly, this paper explores the reasons for the differences between the farmers' willingness and behavior from two perspectives: adaptive expectations at the micro-level and substitution effect between labor and capital input at the macro level. The conclusions of this paper have strong implications for the formulation of policies related to agricultural technology services in the Mid-East region of China.

\section{Methodology}

\subsection{Analysis Framework}

Farmers' grain production investment can be divided into capital input and labor input. The former includes not only variable costs in the process of grain production (such as purchasing seeds, fertilizers, pesticides, rental of agricultural machinery, and land contractual management right), but also fixed assets (such as investment in agricultural machinery and transportation vehicles) [38,39]. The latter includes farmers' labor input, workers, technical services, and information services [37]. There are many factors affecting farmers' willingness to adjust grain production investment, including economic, policy, and natural factors. The farmers' willingness and actual behavior can be directly affected by economic factors [21], and indirectly affected by other factors. Therefore, this paper focuses on the economic factors, including capital and labor input, attitudes, and the characteristics of farm households.

The main question to be answered is whether the farmers who had the willingness to adjust investment had actual adjustment behavior during the study period. The adjustment of the investment structure in grain production is categorized into four kinds:

(1) Had the willingness and have increased their investment;

(2) Had the willingness and have decreased their investment;

(3) Had the willingness but have not adjusted their investment; and

(4) Did not have the willingness and have not adjusted their investment.

In theory, there are both micro and macro reasons for the differences between willingness and actual behavior (see Figure 1). At the micro-level, the adjustment of grain production investment needs not only willingness but ability [40]. At the macro level, the capital and labor market of the whole region is relatively stable, so it takes time to increase grain output through capital input, and the short-term output elasticity is relatively low [41].

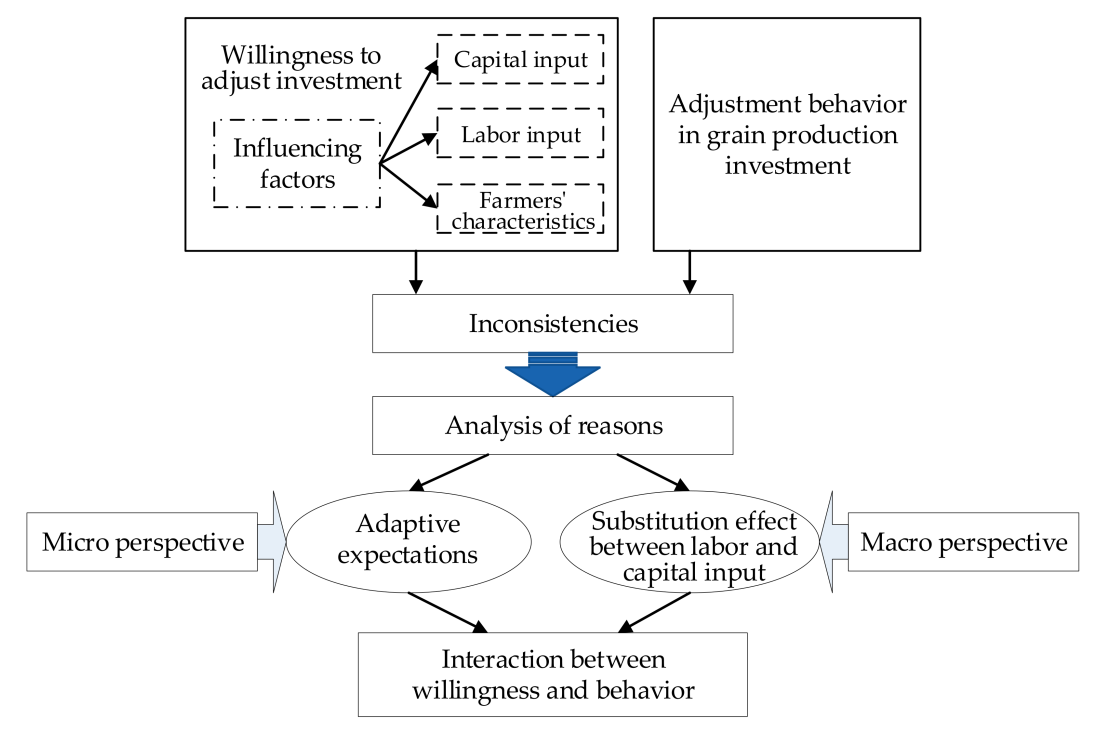

Figure 1. Analysis framework. 


\subsection{Model Selection}

In this paper, we employ three types of models: Multinomial Logistic Model, Adaptive Expectations Model, and Output Elasticity of Capital and Labor, and analyze the factors influencing willingness to invest, and the reasons for differences between willingness and actual behavior.

\subsubsection{Multinomial Logistic Model}

The Multinomial Logit Model is used when the dependent variable has multiple unordered nominal categories [10]. Farmers' willingness to invest in grain production is divided into three categories: the increase in investment, remaining constant, and the decrease in investment. These dependent variables are categorical rather than ordinal, and they conform to the assumption of Independence of Irrelevant Alternatives (IIA), and any two types of results that are independent of each other. Therefore, following Amemiya [42], we establish the Multinomial Logistic Model. The farmers' willingness to adjust their investment is essentially a problem of maximizing their utility. Suppose a farmer (i) chooses option $j$ because its utility is higher than all the other alternatives. The probability that the farmer $i$ chooses the option $j$ is:

$$
P_{i j}=\frac{\exp \left(x_{i j} \beta\right)}{\sum_{j=0}^{J} \exp \left(x_{i j} \beta\right)}
$$

In Formula (1), the explanatory variable $x_{i}$ only changes with the individual variable (farmer $i$ ), not with option $j$.

We can use Option 1 as the reference option and its coefficient $\beta_{i}=0$, then the probability of farmer $i$ choosing option $j$ is:

$$
P\left(y_{i}=j \mid x_{i}\right)=\left\{\begin{array}{l}
\frac{1}{1+\sum_{k=2}^{J} \exp \left(x_{i} \beta_{k}\right)}(j=1 ; \forall k \neq j) \\
\frac{\exp \left(x_{i} \beta_{j}\right)}{1+\sum_{k=2}^{J} \exp \left(x_{i} \beta_{k}\right)}(j=2, \ldots, J ; \forall k \neq j)
\end{array}\right.
$$

The willingness to invest in grain production is divided into three types, which can be explained by the odds ratio. The ratio of the odds of " $m$ " to the odds of " $n$ " can be computed as:

$$
\frac{P(y=m \mid x)}{P(y=n \mid x)}=\frac{\frac{\exp \left(x_{i} \beta_{m}\right)}{\sum_{j=1}^{J} \exp \left(x_{i} \beta_{j}\right)}}{\frac{\exp \left(x_{i} \beta_{n}\right)}{\sum_{j=1}^{I} \exp \left(x_{i} \beta_{j}\right)}}=\frac{\exp \left(x_{i} \beta_{m}\right)}{\exp \left(x_{i} \beta_{n}\right)}
$$

The logarithm of the function:

$$
\ln \left(\frac{P_{i m}}{P_{\text {in }}}\right)=x_{i}\left(\beta_{m}-\beta_{n}\right)
$$

\subsubsection{Adaptive Expectations Model}

The Adaptive Expectations Model was proposed by Nerlove [43] to examine the impact of policy changes on the sown area and grain output. It is assumed that the farmers adjusted the sown area according to the expected price of factor inputs. Following Cheng et al. [44], to investigate the farmers' ability to adjust investment, the Adaptive Expectations Model is established.

$$
G_{t}=a_{t}+b_{t} P_{t}^{e}+\mu_{t}
$$


where $G_{t}$ is the expected sown area, $P_{t}^{e}$ is the expected input price, $a$ and $b$ are coefficients, and $\mu_{t}$ is the stochastic disturbance term, subject to the distribution $N\left(0, \sigma^{2}\right)$. Since the expected price is difficult to measure, the expected price needs to be processed as follows:

$$
P_{t}^{e}=P_{t-1}^{e}+\varepsilon\left(P_{t}-P_{t-1}^{e}\right)
$$

where $P_{t}-P_{t-1}^{e}$ is the predicted deviation of the price of the last period, and $\varepsilon$ is the error-adjustment. The closer the error-adjustment approaches zero, the more accurate the prediction is. Substituting (6) into (5):

$$
G_{t}=\lambda_{0}+\lambda_{1} G_{t-1}+\lambda_{2} P_{t-1}+\mu
$$

where $G_{t}$ and $G_{t-1}$ represent the sown area of the current period and the one-period lag respectively, and $P_{t-1}$ is the input price of the one-period lag.

Let $\gamma=1-\lambda_{1}, \gamma$ is the adjustment coefficient, which indicates the ability of farmers to adjust the sown area according to various factors such as the market price of factor inputs and the situation of land circulation. To make the residuals of the model stochastic, we take the logarithm of the variables, and the sown area adjustment model is specified as the following:

$$
\ln G_{t}=\lambda_{0}+\lambda_{1} \ln G_{t-1}+\lambda_{2} \ln P_{t-1}+\mu_{t}
$$

\subsubsection{Output Elasticity of Capital and Labor}

The yield of three types of major crops per $\mathrm{Mu}$ (in kilograms) is taken as the output; The quantity of the labor force per $\mathrm{Mu}$ (the number of persons per day) is taken as the labor input; The average material and service cost per $\mathrm{Mu}$ (in Yuan) is taken as the capital input.

Compared with other production function models, Cobb-Douglas function has more advantages in calculating the output elasticity of labor and capital, so we use the Cobb-Douglas production function, " $Y=A K^{\alpha} L^{\beta}$ " where " $Y$ " is the output, " $K$ " is the capital input, " $L$ " is the labor input, " $A$ " is the total factor productivity, and " $\alpha$ " and " $\beta$ " are the output elasticity of capital and labor, respectively. Following Ito and $\mathrm{Ni}$ [45], the logarithm of the function can be written as: $\ln Y=\ln A+\alpha \ln K+\beta \ln L$.

Assuming that the returns to scale are constant $(\alpha+\beta=1)$ and technological progress can be ignored in the short term, the function can be written as follows:

$$
\alpha=\frac{\ln Y-\ln L}{\ln K-\ln L}
$$

The marginal productivity of the two factors based on the output elasticity of labor and capital can be calculated as the following:

$$
M P K=\alpha \frac{Y}{K}
$$

where $\alpha$ is the output elasticity of capital, $Y$ is the grain output, and $K$ is the capital input.

$$
M P L=(1-\alpha) \frac{Y}{L}
$$

where $1-\alpha$ is the output elasticity of labor, $Y$ is the grain output, and $L$ is the labor input.

\section{Farmers' Willingness to Invest in Grain Production}

This section may be divided by subheadings. It should provide a concise and precise description of the experimental results, their interpretation, as well as the experimental conclusions that can be drawn. 


\subsection{Data, Variables and Descriptive Statistics}

In modern China, many institutes and researchers strive to find ways to implement a rural revitalization strategy and promote the integration of urban and rural development. The coordinated development of agriculture in the Mid-East region has become an important issue in China. To investigate the current situation of urban farmers' investment behavior in grain production, 60 villages in the area were investigated by the authors from July to August 2018. The survey used a combination of typical investigations, random sampling, cluster sampling, and interviews. We conducted questionnaires, face-to-face interviews, and the survey was based on farm households. The survey mainly included basic characteristics of farm households, variable costs of grain production, characteristics of operations, income from grain production, and farmers' attitudes towards grain production. We surveyed 672 farm households, and 609 valid questionnaires were received. The effective rate was $90.5 \%$.

In this paper, the farmers' willingness to invest in grain production is the explained variable. Explanatory variables are divided into three types: capital input, labor input and attitudes, and characteristics of farm households. Capital input reflects the willingness to invest from different aspects, including seed (seed), fertilizer (ferti), pesticide (pestc), irrigation (irrga), and machinery (mech) costs. The differences in labor input and attitudes have different effects on the willingness to adjust investment, including the number of farmers (farm), days of seasonal workers hired (emplo), attitudes toward scale of land (satti), attitudes toward land transfer (tatti), and attitudes toward using fertilizers (fatti). The characteristics of farm households were then divided into seven aspects: scale of agricultural land (scale), sown area (area), change in sown area (achan), proportion of agricultural income (arati), proportion of grain production income (grati), level of education (educ), and distance from farmland to home (dist). The description of variables and their descriptive statistics are shown in Table 1. The farmers' food production behavior questionnaire is shown in Appendix A.

Table 1. Description of variables and descriptive statistics.

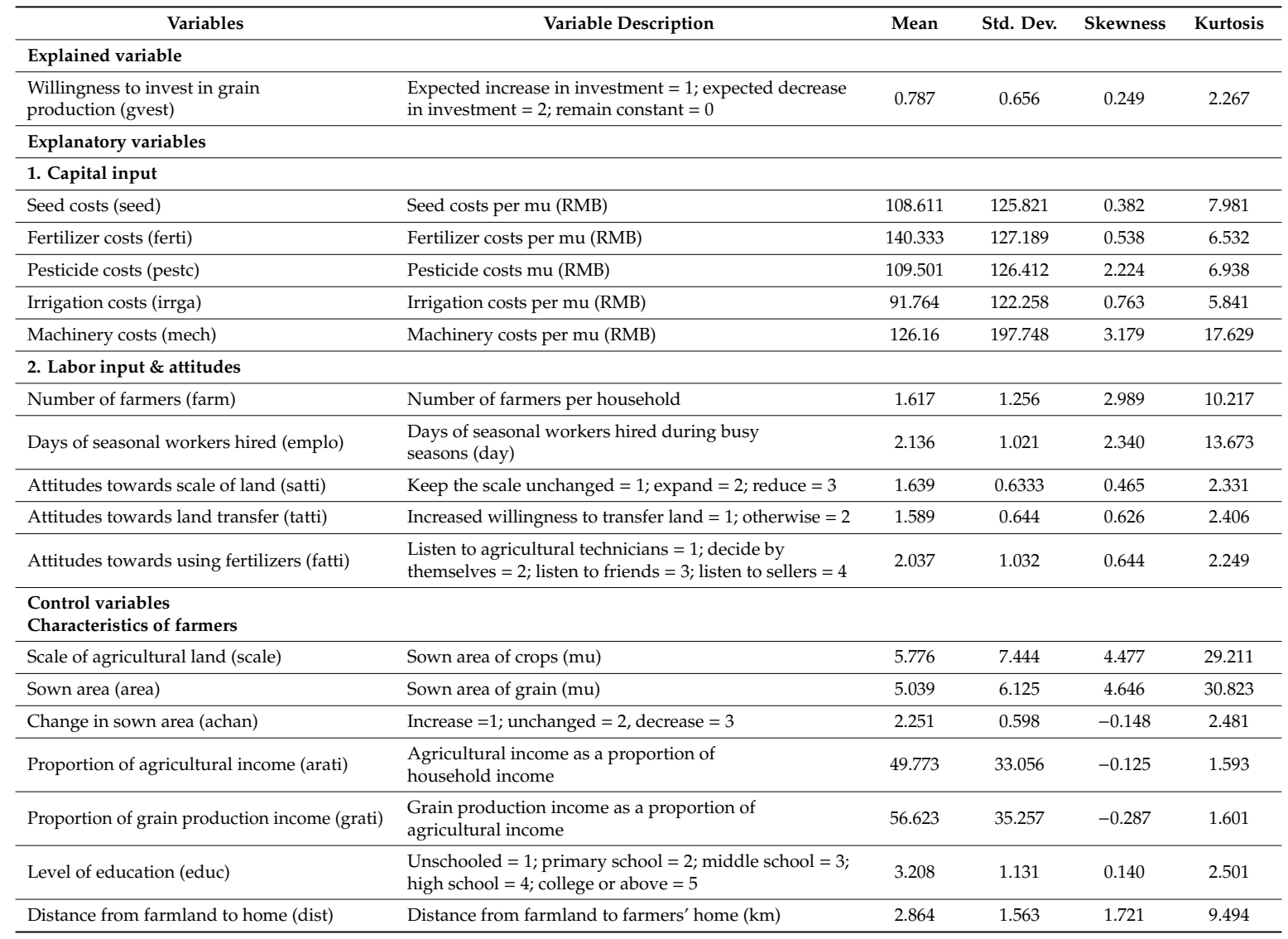


Table 1 shows that the mean of the willingness to invest in grain production is 0.787 . As for capital input, the average expenditure for seeds, fertilizers, pesticides, irrigation, and machinery was 108.6 Yuan, 140.3 Yuan, 109.5 Yuan, 91.8 Yuan, and 126.2 Yuan, respectively, while the standard deviation reflects relatively large dispersion between individuals. As to labor input and attitudes, the mean household size and the number of farmers per household is 3.8 and 1.6, respectively; the percentage of farmers in a household is less than $50 \%$. During the busy seasons, the number of days seasonal workers were hired was 2.136 days. When it comes to the attitudes toward grain growing, more than half of the farm households tend to expand the scale of land. Besides, most farmers decided on the use of fertilizers on their own.

Concerning the characteristics of farm households, the average scale of agricultural land and sown area was $5.8 \mathrm{Mu}$ and $5.0 \mathrm{mu}$, respectively. The skewness coefficients of these two variables are the largest, showing a right-skewed distribution. This indicates that the existence of a small number of farmers with large-scale farmland results in the distribution having a long right tail. At the same time, their kurtosis coefficients are also the largest, indicating that the distribution has many outliers. The proportion of agricultural income and the proportion of grain production income was $49.8 \%$ and $56.6 \%$, respectively. The change in sown area was 2.3 , indicating that the overall grain planting area had a decreasing trend. The average age of farmers is concentrated in the middle age of 45-55 years.

\subsection{Regression Results and Discussion of the Multinomial Logit Model}

Based on the influencing factors, the Multinomial Logit Model is employed as follows:

$$
\ln \left(\frac{P_{\text {im }}}{P_{\text {in }}}\right)=\beta_{0}+\beta_{1} \text { capit }_{i}+\beta_{2} \text { labor }_{i}+\beta_{3} \text { famer }_{i}+\varepsilon_{i}
$$

where $\ln \left(\frac{P_{\text {im }}}{P_{\text {in }}}\right)$ is the log-odds ratio; capit $_{i}$ is the capital input, consists of five variables: seed, ferti, pestc, irrga, mech; labor $_{i}$ is the labor input and attitudes, consists of five variables: farm, emplo, satti, tatti, and fatti; famer $_{i}$ is the characteristics of farm households, consists of seven variables: scale, area, achan, arati, grati, educ, and dist.

We used Stata15.0 software to run the regression. Through the Multinomial Logit Model, we conducted an empirical test to investigate the willingness to invest in grain production in the specified region. Additionally, we set the group of remaining unchanged as the Control Group, analyze the odds of increasing/decreasing investment, and compared to the odds of keeping investment unchanged. The regression results are shown in Table 2.

Table 2. Farmers' willingness to adjust grain production investment.

\begin{tabular}{ccccccc}
\hline \multirow{2}{*}{ Influencing Factors } & \multicolumn{3}{c}{ Increase in Investment } & \multicolumn{3}{c}{ Decrease in Investment } \\
\cline { 2 - 7 } & $\beta$ & S.E. & $\exp (\beta)$ & $\beta$ & S.E. & exp( $\beta)$ \\
\hline Capital input & & & & & & \\
seed & -0.0198 & 0.0203 & 0.9981 & 0.0767 & 0.0204 & 1.0076 \\
ferti & 0.0146 & 0.0114 & 1.014 & -0.0173 & 0.0112 & 1.0172 \\
pestc & $0.0149^{*}$ & 0.0188 & 1.015 & 0.0812 & 0.0185 & 1.0081 \\
irrga & $0.071^{*}$ & 0.0066 & 1.0513 & -0.2348 & 0.0067 & 0.8792 \\
mech & $0.03533^{* *}$ & 0.0186 & 1.0360 & 0.0403 & 0.1792 & 1.0411 \\
Labor input \& attitudes & & & & & & \\
farm & $-1.7464^{* * *}$ & 0.6286 & 0.1744 & $1.5839 * *$ & 3.6044 & 4.8980 \\
emplo & 0.5801 & 0.4037 & 1.7861 & 0.5972 & 0.2941 & 1.8171 \\
satti & -0.3355 & 0.6911 & 0.7151 & -0.7767 & 1.4093 & 0.9252 \\
tatti & $-0.4218^{*}$ & 0.2118 & 0.6558 & $-2.3008 *$ & 0.3187 & 9.9825 \\
fatti & $0.9463^{*}$ & 0.3619 & 2.5762 & 1.2333 & 0.5762 & 3.432 \\
Characteristics of farm households & & & & & \\
scale & 0.1232 & 0.0136 & 0.9946 & -0.1287 & 0.5164 & 0.8792 \\
area & $0.1493^{* *}$ & 0.0263 & 0.8613 & -0.0548 & 0.6671 & 0.9466 \\
achan & 0.5779 & 1.0263 & 0.5783 & 0.3028 & 0.5761 & 1.3536 \\
arati & $0.0173^{*}$ & 0.0184 & 1.0176 & $-0.0112 *$ & 0.0182 & 0.9889 \\
grati & $0.0545^{* *}$ & 0.0287 & 1.0560 & 0.0586 & 0.0272 & 1.0603 \\
educ & $0.1761^{*}$ & 0.2055 & 1.1932 & -0.6358 & 0.7204 & 0.5295 \\
dist & 0.2873 & 0.0437 & 1.3328 & $-0.2897 * *$ & 0.2085 & 0.7485 \\
\hline
\end{tabular}

Note: $\beta$ is the coefficient; S.E. is the standard deviation; $\exp (\beta)$ is the odds ratio. ${ }^{* * *},{ }^{* *}$, and ${ }^{*}$ indicate $p<0.01, p<$ 0.05 , and $p<0.1$, respectively. 


\subsubsection{Factors Affecting Capital Input}

Among the various factors affecting capital input, the quality of seeds affected grain productivity to a large extent. For the farmers in this region, using self-retained seeds is uncommon, and most of the seed expenditures are cash expenditures. Also, timely irrigation is another important factor that improves productivity. Therefore, the high cost of high-quality seeds and irrigation means active investment behavior of farmers in grain production.

Furthermore, fertilizers have a significant effect on increasing the yield in small-scale farming. Under the existing scale of land, only increasing the yield on a per-area basis can achieve higher profits, and increasing the yield by increasing the application of fertilizers is more suitable for smallholder farmers [46]. In contrast, pesticides are more appropriate for large-scale operations. Those who operate large-scale farmland have sufficient funds, larger planting areas, and serious pest problems so they will increase the use of pesticides [47]. What is more, the large farmland with high mechanization levels brings higher income for large-scale farms. The high machinery costs mean that the mechanization adoption rate is relatively high, and the investment behavior of farmers in grain production is more active.

Table 2 shows that the farmers are willing to increase their investment in pesticides, irrigation, and machinery. The sign and magnitude of the coefficients indicate the possibility that the farmers choose to increase investment. The coefficient of machinery costs in the model is 0.0353 , which represents that for every unit of increase in machinery costs, the probability of farmers choosing to expand investment increase by $3.53 \%$. Concerning the impact of fertilizer costs, it is not significant, and the possible reason is the lack of government incentives and constraints on grain production has led to technological backwardness in the use of fertilizers [48]. Farmers are over-reliant on fertilizers, and over-fertilization has led to the deterioration of soil, environmental pollution, and a decline in the quality of agricultural products. Hence, reducing the use of fertilizers and promoting directive fertilization has become increasingly popular in recent years.

\subsubsection{Factors Affecting Labor Input and Attitudes}

The amount of labor input is inseparable from the scale of farmland. Farm households with small-scale land mainly rely on their own labor force, rarely hiring workers. Their level of mechanization is relatively low. However, for farm households with medium and large-scale farmland, their families' labor force is not able to meet the demand for farming, and the cost of workers will increase substantially. Also, Lu et al. [49] indicate that the expansion of the scale of operation leads to economies of scale. The farmers with large-scale land will invest in machinery, improving the degree of mechanization. Therefore, large scales of land lead to less labor input per $\mathrm{Mu}$, and more capital input in grain production.

In the comparison between a decrease in investment and remaining constant, the number of farmers per household significantly affects the farmers' willingness to invest at a significance level of $5 \%$. The odds are 4.89 times higher than farmers who choose to increase investment compared to remaining constant. On the one hand, it shows that an abundant labor force has a significant substitution effect on capital input during busy seasons [31,37]. This also indicates that it is common for rural citizens who are in households with extra laborers, to become part-time farmers and find off-farm employment [50]. Due to the comparatively low benefits of farming, non-agricultural work becomes more attractive for farm households, so their attitudes toward increasing investment in grain production will be negative. As for the number of workers, it has little influence on the willingness of farmers to adjust their investment. The possible reason is that the labor input in grain production is decreasing year by year as the labor costs are accelerating, and the proportion of labor input in grain production has reduced significantly in recent years [51].

The willingness to transfer land has also had a significant impact on the investment behavior of farmers. The odds for increasing investment are approximately $34.4 \%$ lower than the odds for remaining constant. The proportion of non-agricultural income in the household's income is a critical factor that affects farmers' willingness to participate in land transfer. The strong willingness to transfer 
land typically indicates the small proportion of agricultural income, so farmers tend to reduce the scale of operation. As for farmers' attitudes towards the scale of land, it had no significant impact on the willingness to adjust investment. A possible reason is that the scale of different farmland and the grain yield per Mu show an inverted U-shaped relationship. Specifically, the land that is below the optimal scale will not be able to produce grain efficiently, even if there is a large amount of capital input [49]. Besides farmers' attitudes toward the use of fertilizers, pesticides significantly affect investment behavior. With positive attitudes towards the use of fertilizers, the odds of increasing investment are about 2.58 times higher than the odds of remaining constant.

It is worth noting that the coefficients of labor input and attitudes are generally larger than that of capital input, which indicates that the marginal utility of labor input is significantly greater than that of capital input.

\subsubsection{Factors Affecting Characteristics of Farm Households}

For most farm households, a high agricultural income means more reliance on agricultural technologies [52]. The higher the proportion of agricultural income in a household's income means that grain production is important for the farm's household. Therefore, farmers have more incentive to invest in grain production.

Compared with the group of remaining unchanged, the sown area and the proportion of grain production income have a significant impact on the increase in investment at the significance level of $5 \%$, and the proportion of agricultural income positively impacts the investment at the significance level of $10 \%$. This shows that with the expansion of the scale of agricultural land and the increase in agricultural income, the hypothesis of rational economic man is gradually becoming obvious. Farmers focus more on the optimal allocation of production factors in order to maximize the overall benefit. At the same time, in the comparison between a decrease in investment and remaining constant; the proportion of agricultural income has a significant impact on investment decisions. The coefficient is -0.0112; that is, for every unit increase in the proportion of agricultural income, the probability of farmers choosing to reduce investment is reduced by $1.12 \%$, indicating that the higher proportion of agricultural income typically means the smaller proportion of part-time farmers and non-agricultural employment, and the farmers are less likely to reduce investment in grain production. Under the condition that other variables remain unchanged, the education factor also affects farmers' investment decisions. The probability of choosing increasing investment is 1.19 times than that of choosing to remain unchanged. This is because the farmers with a high level of education have strong abilities to use new technologies, and they prefer to increase investment in grain production.

\section{Differences between Farmers' Willingness and Behavior}

\subsection{Analysis Based on the Perspective of Adjustment Capability}

\subsubsection{Description of Differences}

We investigate whether the farmers' willingness to adjust grain-growing investment had been implemented in January 2019 through telephone surveys. Among the 378 farm households who had the willingness to adjust the investment in grain production six months ago, only 107 households had adjusted, accounting for $27.2 \%$. The remaining 271 households had not changed their original investment scale. Among the farmers who had adjusted the investment, 78 households had increased the scale of investment, while 29 households had reduced the investment.

\subsubsection{Reasons for the Differences}

Only a few farmers who had the willingness to adjust the grain production investment had adjusted the scale of investment, and most farmers' actual behavior deviated from their willingness. The reasons were as follows. 
Firstly, in this region, the characteristics of urban agriculture are obvious. The land transfer rate is low, and the effect of land transfer on grain productivity gradually declines. The scale of production is small, which limits the effectiveness of large-scale agricultural machinery. Therefore, in the short-term, the adjustment of the investment structure is hard to implement [49,53]. Secondly, agricultural technologies, such as improved seeds and water-saving irrigation, play an increasingly important role in the transition from traditional agriculture to modern agriculture [54].

Significant differences exist in the supply and demand of agricultural technologies and farmers' technology choice behavior, and it takes time for first-time users to learn to apply new techniques into practice [55]. Thus, only having the willingness is not enough. Farmers also need the ability and time to adjust investment structures.

The reasons for the inconsistencies between the willingness and the actual behavior need to be further quantitatively analyzed. The Adaptive Expectations Model for investment adjustment can be formulated as follows:

$$
\begin{aligned}
\ln G_{t}= & 1.416+0.359 \ln G_{t-1}+0.403 \ln P_{t-1}+\mu_{t} \\
& (1.553)(1.621)
\end{aligned}
$$

$F=33.627, R^{2}=0.867$, where the values in parentheses are the $t$-statistics of the parameter estimates.

The value of $\gamma$ is 0.641 obtained by $1-\lambda_{1}$, and its reciprocal is the time required to adjust the planting area, which is 1.56 years. This means that it takes more than a year and a half to prepare for an adjustment in investment structure and planting area. The effects of lagged adjustment reveal the reasons for the inconsistencies between the willingness and the actual behavior, and explain why most of the farmers willing to adjust investment had not implemented the adjustments in the short term.

\subsection{Analysis Based on the Perspective of Substitution Effect}

\subsubsection{Substitution Effect between Labor and Capital Input}

With an increase in the opportunity cost of farming, a large number of young and middle-aged laborers in rural areas find non-agricultural jobs in cities [6], so replacing the labor input with machinery input becomes an advisable option in modern agriculture. According to the China Agricultural Products Cost-Benefit Compilation of Information, the number of days workers were hired per $\mathrm{Mu}$ in grain production decreased from 9.59 days in 2005 to 5.04 days in 2017; the labor input has decreased overall by $47.4 \%$. At the same time, the machinery input has increased from 37.73 Yuan in 2005 to 145.72 Yuan in 2017; the fertilizer input has also increased by 55.2\%. [41] indicates that the methods of grain production in China have been changed. The labor force used in grain production has dropped significantly, and it has been replaced by agricultural machinery to a large extent. The inputs of machinery, fertilizers, and pesticides have increased remarkably.

$\mathrm{Lu}$ and Xie [51] have revealed that economies of scale could be achieved through land transfer, and marginal costs of inputs such as labor and fertilizers can be reduced. Therefore, the traditional labor-intensive grain production mode is gradually transforming. A large amount of labor input in grain production is shifting toward capital input.

Table 3 shows the Pearson correlations between labor input and machinery/fertilizer input in grain production in China from 2000 to 2017.

Table 3. Pearson correlations between labor input and machinery and fertilizer input.

\begin{tabular}{ccccc}
\hline Category & $\begin{array}{c}\text { National Average } \\
\text { Labor Input }\end{array}$ & $\begin{array}{c}\text { Labor Input in } \\
\text { Beijing }\end{array}$ & $\begin{array}{c}\text { Labor Input in } \\
\text { Tianjin }\end{array}$ & $\begin{array}{c}\text { Labor Input in } \\
\text { Hebei }\end{array}$ \\
\hline Machinery input & $-0.940^{* *}$ & $-0.467^{*}$ & $-0.478^{*}$ & $-0.953^{* *}$ \\
Fertilizer input & $-0.962^{* *}$ & -0.120 & -0.752 & $-0.952^{* *}$ \\
\hline
\end{tabular}

Note: ** and * indicate the significance levels of 0.01 and 0.05 , respectively. The data for Beijing and Tianjin is from 2001 to 2007 due to the limitations of the statistical yearbook. 
The information collected from the survey shows that in the answers to "your attitude towards the adoption of new technologies", the proportion of farmers who chose "adopt new technologies after knowing the effectiveness" accounted for $41.6 \%$, much higher than that of farmers who chose "immediately adopt new technologies" and "adopt new technologies after other people have adopted". As for the answers to "the main purpose of adopting new technologies"; "reducing labor input" accounted for $33.7 \%$, second only to "increasing yield".

In the process of grain production, the reasons for decreasing labor input are as follows.

With the rising opportunity cost of being engaged in agriculture, a large number of young adults in rural areas find non-agricultural jobs in cities, and the structure of the rural labor force shifts from surplus to a structural shortage [6,51]. The loss of laborers has led to extensive farming and even abandoned farmland. Therefore, to reduce labor input, it is a realistic choice to replace the labor input by increasing the level of mechanization. The statistical results of the questionnaires show that in response to the "methods of grain production", the "increased level of mechanization" accounted for $52.3 \%$, which is significantly higher than the other three responses, "more extensive", "more intensive" and "no change".

\subsubsection{Changing Trends in Labor and Return on Capital}

To further clarify the substitution effect between labor and capital, the issue is discussed from the aspects of output elasticity of labor/capital and marginal productivity. According to China Agricultural Products Cost-Benefit Compilation of Information, there are two turning points (1990 and 2006, respectively) that the number of workers hired in grain production changed significantly. Therefore, the output elasticity of labor and capital for japonica rice, wheat, and corn are calculated for three periods: 1978-1990, 1991-2006, and 2007-2017.

Table 4 reports elasticity and marginal productivity of labor and capital (1978-2017).

Table 4. Output elasticity and marginal productivity of labor and capital (1978-2017).

\begin{tabular}{cccc}
\hline & $\mathbf{1 9 7 8 - 1 9 9 0}$ & $\mathbf{1 9 9 1 - 2 0 0 6}$ & $\mathbf{2 0 0 7 - 2 0 1 7}$ \\
\hline Japonica rice & & & \\
Output elasticity of labor & 0.013 & 0.119 & 0.187 \\
Marginal productivity of Labor $(\mathrm{kg})$ & 0.219 & 4.306 & 13.658 \\
Output elasticity of capital & 0.987 & 0.881 & 0.813 \\
Marginal productivity of capital (kg) & 8.422 & 6.732 & 6.021 \\
Wheat & & & \\
Output elasticity of labor & 0.024 & 0.069 & 0.232 \\
Marginal productivity of Labor $(\mathrm{kg})$ & 0.361 & 2.322 & 23.413 \\
Output elasticity of capital & 0.976 & 0.931 & 0.768 \\
Marginal productivity of capital (kg) & 6.126 & 5.624 & 4.727 \\
Output elasticity of labor & 0.139 & 0.191 & 0.326 \\
Corn & & & \\
Marginal productivity of Labor $(\mathrm{kg})$ & 2.378 & 6.005 & 20.313 \\
Output elasticity of capital & 0.861 & 0.809 & 0.674 \\
Marginal productivity of capital (kg) & 9.351 & 8.273 & 6.356 \\
\hline
\end{tabular}

Source: Calculated based on the data from China Agricultural Products Cost-Benefit Compilation of Information (1979-2018).

Table 4 shows that the marginal productivity of labor of the three kinds of crops has increased gradually; the output elasticity of labor has also increased. It is noticeable that from 2007 to 2017 , the marginal productivities of labor for the three kinds of crops have increased significantly. To be specific, the figure for japonica rice, wheat, and corn has increased by 2.18, 9.08, and 2.38 times, respectively, reflecting that the labor-intensive production pattern is changing in China. Besides, the marginal productivity and output elasticity of capital show a gradual decline during the period of 1979 to 2017. The marginal productivities of capital for japonica rice, wheat, and corn have decreased by $10.6 \%$, 
$15.1 \%$, and $23.2 \%$, respectively, from 2007 to 2017 . The reduction of marginal productivity of capital for the three crops is far less than the increase in the marginal productivity of labor. Therefore, under the constraints of relatively scarce production factors and land fragmentation, the decline in return on capital and investment has become an inevitable trend.

\subsubsection{Reasons for the Differences between Farmers' Willingness and the Actual Behavior}

The cost-benefit data for Mid-East China region has no longer been presented in the statistical yearbook since 2008. Hence, we calculate the output elasticity of capital of the three kinds of crops, in the short term, based on the statistical data from 2006 to 2007. Using Equation (6), the calculation results are shown in Table 5.

Table 5. Capital output elasticity of Beijing, Tianjin and Hebei in 2006-2007.

\begin{tabular}{ccccc}
\hline & Beijing & Tianjin & Hebei & Average in China \\
\hline Japonica rice & - & 0.527 & 0.429 & 0.488 \\
Wheat & 0.483 & 0.556 & 0.478 & 0.469 \\
Corn & 0.636 & 0.635 & 0.547 & 0.513
\end{tabular}

Source: Calculated based on the data from China Agricultural Products Cost-Benefit Compilation of Information (1979-2018).

It can be seen from Tables 4 and 5 that the short-term output elasticity of capital for wheat in Mid-East China during 2006-2007 is $0.483,0.556$, and 0.478, respectively, slightly higher than the average value in China. However, they are lower than the long-term output elasticity of capital during 1991-2006 and 2007-2017 (0.931 and 0.768 respectively), which suggests that it takes time to improve wheat yield through capital input, such as improving soil fertility and agricultural infrastructure. The long-term output elasticity of capital for wheat is greater than the short-term output elasticity, which indicates that the capital input has a positive impact on wheat productivity in the long term.

Similarly, the output elasticity of capital for rice and corn reflects that the short-term output elasticity of capital is less than the long-term output elasticity, which explains why most of the farmers who had the willingness to adjust investment had not implemented the adjustments in the short term at the macro-level.

\section{Conclusions and Implications}

This paper first constructs a Multinomial Logit Model based on a survey of 609 farmers and analyzes the influencing factors of farmers' willingness to adjust their grain production and investment. Also, this paper further investigates the reasons for the differences between farmers' willingness and the actual behavior from the perspective of adaptive expectations at the micro-level and substitution effect between labor and capital input at the macro-level. The main conclusions of this paper are as follows.

First, factors such as irrigation costs, machinery costs, number of farmers, willingness to transfer land, the scale of operation, and proportion of grain income have significant influences on farmers' willingness to adjust investment. Among the variables of capital input and labor input \& attitudes, the most significant factors that affect the farmers' willingness are the cost of machinery and number of farmers, respectively. Second, most of the farmers who had the willingness to adjust investment did not implement the adjustments in the short term, because their willingness is affected by adjustment capabilities and the time required to implement the adjustment. Third, at the micro-level, the time required to adjust the planting area is the main reason for the differences between the farmers' willingness and actual behavior. The actual adjustment always lags behind their willingness. Fourth, at the macro-level, the main reason for the differences is that the short-term output elasticity of capital is less than the long-term output elasticity, so it needs a process to improve the grain output by increasing capital input. 
Based on these conclusions, this paper has the following implications:

Firstly, it is important to improve the cost control mechanism for variable factors in grain production. In the current era, the cost of labor is rising, the cost of grain production is high, and the increase in grain prices is far behind the price increases. Hence, it is necessary to control the variable costs of grain production and improve the dynamic adjustment mechanism for agricultural product prices and grain prices. It can solve the problem of price scissors in the field of grain and narrow the gap between the prices of agricultural raw materials and grain prices.

Secondly, it is important to decrease the constraints such as infrastructure and platform resources that affect the scale of operation. It is advisable to expand the scale of operations and improve the agricultural infrastructure to combat the problem that the proportion of grain output and income in the Mid-East region of China is declining. Moreover, driven by the agricultural supply-side structural reform in China, the government should strive to improve the agricultural information and cooperation platforms to promote the modernization of the agriculture industry.

Thirdly, local governments should strengthen technical research with big data in agriculture and scientifically guide market expectations. It is essential to improve the agricultural data collection and analysis systems, track market changes in real-time, forecast grain supply and demand, and explore innovative farming methods. Besides, local governments can use big data and cloud computing to provide more accurate advice regarding agricultural production and promote the development of intelligent agriculture.

Author Contributions: Conceptualization, S.W. and Y.T.; Methodology, S.W. and Y.T.; Software, Y.T. and X.L.; Validation, Y.T. and M.F.; Investigation, Y.T. and X.L.; Data curation, S.W. and Y.T.; Writing-original draft preparation, S.W. and Y.T.; Writing—review \& editing, M.F.; Visualization, Y.T.; Supervision: X.L.; Project administration, S.W.; Funding acquisition, S.W. and Y.T. All authors have read and agreed to the published version of the manuscript.

Funding: This research was funded by the Major Social Science Project of Tianjin Education Commission, grant number 2019JWZD48; Social Science Project of Ministry of Education, grant number 17JHQ034; and Tianjin Science and Technology Development Strategy Research Project, grant number 18ZLZDZF00020.

Conflicts of Interest: The authors declare no conflict of interest.

\section{Appendix A Farmers' Food Production Behavior Questionnaire}

\section{Appendix A.1 Characteristics of Farm Households}

1. Gender. A. Male B. Female

2. Age. A.16-30 years B. 31-45 years C. 46-60 years D. Over 60 years old

3. Level of education. A. Unschooled B. Primary school C. Middle school D. High School E. College or above

4. How many people are there in your family? How many people are engaged in agriculture in your family? How many people are engaged in non-agricultural work in your family? What is the average wage per day for the people that are engaged in non-agricultural work?

5. The location of your home: Plains/Hills/Mountain areas? The distance from your home to the center of the town or the market? Transportation: Convenient/inconvenient?

\section{Appendix A.2 Utilization of Cultivated Land}

6. What was the cultivated area, the grain sown area, and the abandoned area of your family last year? What was the gross income and the income excluding costs from farming? What were the main costs (multiple answer question)? A. Seed costs B pesticide costs C. Fertilizer costs D. Agricultural film costs E. Agricultural technology service fees F. Machinery costs G. Others

7. Did you shift the land contractual management right?

(1) If yes, a total of mu transferred, annual income is Yuan/mu. 
What was the form of the circulation (multiple answer question)?

A. Exchange with neighbors B. Direct rental C. Establishment of land cooperatives D. Participation in agricultural business entities

What was the main reason for transferring land?

A. Lack of labor B. Low income from farming C. High income from land transfer D. Conducive to looking for non-agricultural jobs

What was the main use of the transferred land?

A. Planting food crops B. Planting cash crops C. Breeding livestock D. Others

(2) If no, what is the main use of the current land?

A. Planting food crops B. Planting cash crops C. Breeding livestock D. Others

What is the reason that you did not transfer land?

A. I want to cultivate crops B. I do not have the ability to go out to work C. I do not want to leave my hometown D. I am satisfied with the income from farming E. Nobody wants to buy the land contractual management right or the price is low so I do not want to transfer

8. Do you have any land that was transferred from others?

(1) No

(2) If yes, the total area is $\mathrm{mu}$, the annual cost is Yuan/mu, and the circulation form is:

A. Exchange with neighbors B. Direct rental C. Others

What is the main use of the land that was transferred from others?

A. Planting food crops B. Planting cash crops C. Breeding livestock D. Others

9. What is your attitude about the scale of your farmland?

A. Keep the existing scale unchanged B. Expand the scale of operations C. Compress the scale of operations

10. Has your land been issued the Certificates of the Right to the Contracted Management of Rural Land?

(1) If yes, after the certificates have been issued, what is your attitude towards land transfer?

A. Increase willingness to transfer land B. Remain unchanged C. Decrease willingness to transfer land

(2) If no, how would the issuance of the certificates affect your attitudes towards land transfer?

A. Increase willingness to transfer land B. Remain unchanged C. Decrease willingness to transfer land

Appendix A.3 Grain Growing Behavior of Farmers

11. What is your attitude towards adjusting your grain-growing investment?

A. increase B. remain unchanged C. decrease

12. What is your household's agricultural income as a proportion of household income? What is your grain production income as a proportion of agricultural income?

13. What is the increase in cost per mu of grain production compared with last year? 


\section{A. Rise slightly B. Rise significantly}

What are the main reasons for the total cost increase (multiple answer question)?

A. Agricultural tool costs B. Seed costs C. Fertilizer costs D. Pesticide costs E. Irrigation costs F. Machinery costs G. Technical service fees H. Others

14. What is the main purpose of your family's grain production?

A. Make money B. Create jobs for family members C. Provide food for family D. Avoid land barren E. Others

15. What are the costs of seeds, fertilizers, pesticides, irrigation, and machinery per mu in this year? What was the average investment per mu in the past?

16. The current situation of your family's grain planting.

Table A1. The current situation of your family's grain planting.

\begin{tabular}{|c|c|c|c|c|c|c|}
\hline & Rice & Wheat & Corn & Beans & Potatoes & Cash Crops \\
\hline $\begin{array}{c}\text { Area (mu) } \\
\text { Average vield per mu (Jin) }\end{array}$ & & & & & & \\
\hline Average output value per mu (RMB) & & & & & & \\
\hline Average cost per mu (RMB) & & & & & & \\
\hline Labor costs (RMB) & & & & & & \\
\hline Cost of means of production (RMB) & & & & & & \\
\hline
\end{tabular}

17. Do you think that your investment has increased compared to last year? A. Yes. B. No

18. Do grain subsidy and improved seeds subsidy have a positive impact on your incentives to expand grain area and increase grain production?
A. Strong incentives B. Some incentives C. Little incentives D. No incentive

19. What measures do you think the government should take to improve farmers' enthusiasm for grain production?

A. Increase food prices B. Increase grain subsidy C. Strengthen the management of agricultural materials' market and reduce grain production costs D. Improve the socialized service system and solve farmers' worries E. Formulate relevant laws and regulations to ensure farmers' land transfer income

20. Do you know the comprehensive direct subsidy policy for agricultural means of production such as diesel and fertilizers?

If you know, the comprehensive direct subsidy of agricultural materials per mu in your family was ___ Yuan in 2017, an increase of ___ Yuan over the previous year.

Did the subsidy you received exceed the increase in the price of agricultural materials? A. Yes B. No

21. Do you know the comprehensive direct subsidy standard of agricultural materials?

If you know, what do you think of the current standard for the comprehensive direct subsidy of agricultural materials?

A. It is high B. It is appropriate C. It is low

22. Do you know the basis of comprehensive direct subsidy of agricultural materials? 
If you know, what is the basis of subsidy?

A. According to the farmland occupation area that levied tax B. According to the actual planting area $\mathrm{C}$. According to the quantity of agricultural means of production actually purchased D. Other ways

What kind of subsidy basis do you want the government to adopt?

Which way do you want the government to grant subsidies?

A. Cash payment B. Bank card payment C. Subsidy voucher

23. Do you know the subsidy policy for agricultural machinery purchases?

When purchasing agricultural machinery, your family Yuan subsidy, accounting for $\%$ of the total value of the machinery.

24. What do you think is the frequency of fake pesticides, fertilizers, and seeds in the agricultural materials market?
A. Infrequent
B. Often C. Frequent

25. What is the main channel for your family to purchase agricultural products (multiple answer question)?

A. Chain stores of agricultural materials companies B. Retail stores of agricultural materials C. Stores in the village D. Cooperatives

26. How do you buy agricultural materials?

A. According to experience B. Listen to agricultural technicians C. Listen to sellers in agricultural material stores D. Listen to neighbors

27. At the time of purchase, does the agricultural material supplier provide you with relevant services, such as usage and after-sales service?

28. What aspects of agricultural materials do you attach importance to? Please rank the following in order of importance to you.

A. Price B. Quality C. Safety D. Packaging E. Service F. Delivery to home G. Others

29. Do you use machinery to sow and harvest grain now? A. Yes B. No

30. Has your family purchased new agricultural machinery in recent years? A. Yes B. No

31. What do you need most in production and operation?

A. Funds B. Cultivated land C. New technologies D. Information E. Sales channels F. Others Appendix A.4 Farmers' Grain Planting Technology

32. Do you have any technical personnel to guide you in planting? A. Yes B. No

If yes, what kind of personnel is currently guiding you?

A. Grain Growers B. Vegetable growers C. Fruit growers D. Others

Does the guidance charge? Are farmers generally willing to guide? Does this kind of guidance have any effect?

33. Is there any agricultural production service organization in or near your village?

If yes, has your family joined in?

If no, do you wish to have an agricultural production service organization? 
34. How do you apply fertilizer?

A. Listen to agricultural technicians B. Decide by yourself C. Listen to neighbors or relatives D. Listen to sellers

35. Have you participated in associations such as professional cooperatives? A. Yes B. No

36. What are the constraints that affect your adoption of new technologies?

A. Financial reasons B. Technical input costs C. Lack of understanding of technologies

37. What are your needs for agricultural technology services (multiple answer question)?

A. Guide in the field B. Promote more high-tech products C. Ensure the quality and effect of the products promoted D. Strengthen service awareness E. Improve after-sales service

38. What do you think are the biggest concerns and risks in planting new varieties?

A. Lack of knowledge of the new varieties' planting technology B. The market price is difficult to predict $C$. The output of new varieties is difficult to guarantee $D$. There are not many sales channels $E$. The natural environment is not suitable

\section{References}

1. Zeng, X.T.; Zhao, J.Y.; Wang, D.Q.; Kong, X.M.; Zhu, Y.; Liu, Z.P.; Dai, W.; Huang, G.H. Scenario analysis of a sustainable water-food nexus optimization with consideration of population-economy regulation in Beijing-Tianjin-Hebei region. J. Clean. Prod. 2019, 228, 927-940. [CrossRef]

2. Adimassu, Z.; Kessler, A.; Hengsdijk, H. Exploring determinants of farmers' investments in land management in the Central Rift Valley of Ethiopia. Appl. Geogr. 2012, 35, 191-198. [CrossRef]

3. Schulte, H.D.; Musshoff, O.; Meuwissen, M.P.M. Considering milk price volatility for investment decisions on the farm level after European milk quota abolition. J. Dairy Sci. 2018, 101, 7531-7539. [CrossRef] [PubMed]

4. Alcon, F.; Tapsuwan, S.; Brouwer, R.; Yunes, M.; Mounzer, O.; de-Miguel, M.D. Modelling farmer choices for water security measures in the Litani river basin in Lebanon. Sci. Total Environ. 2019, 647, 37-46. [CrossRef] [PubMed]

5. Huang, D.; Huang, Y.; Zhao, X.; Liu, Z. How Do Differences in Land Ownership Types in China Affect Land Development? A Case from Beijing. Sustainability 2017, 9, 123. [CrossRef]

6. May, D.; Arancibia, S.; Behrendt, K.; Adams, J. Preventing young farmers from leaving the farm: Investigating the effectiveness of the young farmer payment using a behavioural approach. Land Use Policy 2019, 82, 317-327. [CrossRef]

7. Greiner, R.; Gregg, D. Farmers' intrinsic motivations, barriers to the adoption of conservation practices and effectiveness of policy instruments: Empirical evidence from northern Australia. Land Use Policy 2011, 28, 257-265. [CrossRef]

8. D'Antoni, J.M.; Mishra, A.K.; Joo, H. Farmers' perception of precision technology: The case of autosteer adoption by cotton farmers. Comput. Electron. Agric. 2012, 87, 121-128. [CrossRef]

9. Rutten, C.J.; Steeneveld, W.; Lansink, A.G.J.M.O.; Hogeveen, H. Delaying investments in sensor technology: The rationality of dairy farmers' investment decisions illustrated within the framework of real options theory. J. Dairy Sci. 2018, 101, 7650-7660. [CrossRef]

10. Chellappan, S.; Sudha, R.; Tyler, D.C.; Connelly, J. Investment, adoption, attitude and extent of participation of farmers in soil conservation projects in the Western Ghats of India: Revised topic. Int. J. Soc. Econ. 2015, 42, 251-275. [CrossRef]

11. Bekele, W.; Drake, L. Soil and water conservation decision behavior of subsistence farmers in the Eastern Highlands of Ethiopia: A case study of the Hunde-Lafto area. Ecol. Econ. 2003, 46, 437-451. [CrossRef]

12. Zemo, K.H.; Termansen, M. Farmers' willingness to participate in collective biogas investment: A discrete choice experiment study. Resour. Energy Econ. 2018, 52, 87-101. [CrossRef]

13. Ihli, H.J.; Gassner, A.; Musshoff, O. Experimental insights on the investment behavior of small-scale coffee farmers in central Uganda under risk and uncertainty. J. Behav. Exp. Econ. 2018, 75, 31-44. [CrossRef] 
14. Jensen, K.; Clark, C.D.; Ellis, P.; English, B.; Menard, J.; Walsh, M.; Ugarte, D.D.L.T. Farmer willingness to grow switchgrass for energy production. Biomass Bioenergy 2007, 31, 773-781. [CrossRef]

15. Konrad, M.T.; Nielsen, H.O.; Pedersen, A.B.; Elofsson, K. Drivers of Farmers' Investments in Nutrient Abatement Technologies in Five Baltic Sea Countries. Ecol. Econ. 2019, 159, 91-100. [CrossRef]

16. Lansink, A.O.; van den Berg, M.; Huirne, R. Analysis of strategic planning of Dutch pig farmers using a multivariate probit model. Agric. Syst. 2003, 78, 73-84. [CrossRef]

17. Kidane, T.T.; Wei, S.; Sibhatu, K.T. Smallholder farmers' willingness to pay for irrigation water: Insights from Eritrea. Agric. Water Manag. 2019, 222, 30-37. [CrossRef]

18. Despotovic, J.; Rodic, V.; Caracciolo, F. Factors affecting farmers' adoption of integrated pest management in Serbia: An application of the theory of planned behavior. J. Clean. Prod. 2019, 228, 1196-1205. [CrossRef]

19. Deng, J.; Sun, P.S.; Zhao, F.Z.; Han, X.H.; Yang, G.H.; Feng, Y.Z. Analysis of the ecological conservation behavior of farmers in payment for ecosystem service programs in eco-environmentally fragile areas using social psychology models. Sci. Total Environ. 2016, 550, 382-390. [CrossRef]

20. Adimassu, Z.; Langan, S.; Johnston, R. Understanding determinants of farmers' investments in sustainable land management practices in Ethiopia: Review and synthesis. Environ. Dev. Sustain. 2016, 18, 1025. [CrossRef]

21. Okello, J.J.; Lagerkvist, C.J.; Kakuhenzire, R.; Parker, M.; Schulte-Geldermann, E. Combining means-end chain analysis and goal-priming to analyze Tanzanian farmers' motivations to invest in quality seed of new potato varieties. Br. Food J. 2018, 120, 1430-1445. [CrossRef]

22. Qin, P.; Xu, J.T. Forest land rights, tenure types, and farmers' investment incentives in China An empirical study of Fujian Province. China Agric. Econ. Rev. 2013, 5, 154-170. [CrossRef]

23. Alkon, M.; Urpelainen, J. Trust in Government and Subsidy Reform: Evidence from a Survey of Indian Farmers. Stud. Comp. Int. Dev. 2018, 53, 449-476. [CrossRef]

24. Reise, C.; Musshoff, O.; Granoszewski, K.; Spiller, A. Which factors influence the expansion of bioenergy? An empirical study of the investment behaviours of German farmers. Ecol. Econ. 2012, 73, 133-141. [CrossRef]

25. Abebaw, D.; Haile, M.G. The impact of cooperatives on agricultural technology adoption: Empirical evidence from Ethiopia. Food Policy 2013, 38, 82-91. [CrossRef]

26. Ghadim, A.K.A.; Pannell, D.J.; Burton, M.P. Risk, uncertainty, and learning in adoption of a crop innovation. Agric. Econ. 2005, 33, 1-9. [CrossRef]

27. Mao, H.; Zhou, L.; Ifft, J.; Ying, R. Risk preferences, production contracts and technology adoption by broiler farmers in China. China Econ. Rev. 2019, 54, 147-159. [CrossRef]

28. Aha, B.; Ayitey, J.Z. Biofuels and the hazards of land grabbing: Tenure (in)security and indigenous farmers' investment decisions in Ghana. Land Use Policy 2017, 60, 48-59. [CrossRef]

29. Gao, L.L.; Sun, D.Q.; Huang, J.K. Impact of land tenure policy on agricultural investments in China: Evidence from a panel data study. China Econ. Rev. 2017, 45, 244-252. [CrossRef]

30. Ullah, M.W.; Anad, S. Current status, constraints and potentiality of agricultural mechanization in Fiji. J. Agric. Mech. Asia Afr. Lat. Am. 2007, 38, 39-45.

31. Ji, Y.Q.; Yu, X.H.; Zhong, F.N. Machinery investment decision and off-farm employment in rural China. China Econ. Rev. 2012, 23, 71-80. [CrossRef]

32. Putra, A.R.S.; Pedersen, S.M.; Liu, Z. Biogas diffusion among small scale farmers in Indonesia: An application of duration analysis. Land Use Policy 2019, 86, 399-405. [CrossRef]

33. Ambrosius, F.H.W.; Hofstede, G.J.; Bokkers, E.A.M.; Bock, B.B.; Beulens, A.J.M. The social influence of investment decisions: A game about the Dutch pork sector. Livest. Sci. 2019, 220, 111-122. [CrossRef]

34. Bitterman, P.; Bennett, D.A.; Secchi, S. Constraints on farmer adaptability in the Iowa-Cedar River Basin. Environ. Sci. Policy 2019, 92, 9-16. [CrossRef]

35. Mu, L.; Wang, C.C.; Xue, B.R.; Wang, H.; Li, S.Y. Assessing the impact of water price reform on farmer's willingness to pay for agricultural water in northwest China. J. Clean. Prod. 2019, 234, 1072-1081. [CrossRef]

36. Emerton, L.; Snyder, K.A. Rethinking sustainable land management planning: Understanding the social and economic drivers of farmer decision-making in Africa. Land Use Policy 2018, 79, 684-694. [CrossRef]

37. Marinoudi, V.; Sorensen, C.G.; Pearson, S.; Bochtis, D. Robotics and labour in agriculture. A context consideration. Biosyst. Eng. 2019, 184, 111-121. [CrossRef] 
38. Waldman, K.B.; Blekking, J.P.; Attari, S.Z.; Evans, T.P. Maize seed choice and perceptions of climate variability among smallholder farmers. Glob. Environ. Chang. 2017, 47, 51-63. [CrossRef]

39. Hou, J.; Huo, X.; Yin, R. Land Rental Market Participation and Its Impact on Fixed Investment and Household Welfare: Evidence from Chinese Apple Production Sites. Sustainability 2017, 9, 1961. [CrossRef]

40. Mariyono, J. Stepping up to market participation of smallholder agriculture in rural areas of Indonesia. Agric. Financ. Rev. 2019, 72, 255-270. [CrossRef]

41. Qiao, F.B. Increasing wage, mechanization, and agriculture production in China. China Econ. Rev. 2017, 46, 249-260. [CrossRef]

42. Amemiya, T. Qualitative Response Models. Ann. Econ. Soc. Meas. 1975, 4, 363-372.

43. Nerlove, M. Adaptive expectations and cobweb phenomena. Q. J. Econ. 1958, 72, 227-240. [CrossRef]

44. Cheng, C.H.; Chen, T.L.; Teoh, H.J.; Chiang, C.H. Fuzzy time-series based on adaptive expectation model for TAIEX forecasting. Expert Syst. Appl. 2008, 34, 1126-1132. [CrossRef]

45. Ito, J.; Ni, J. Capital deepening, land use policy, and self-sufficiency in China's grain sector. China Econ. Rev. 2013, 24, 95-107. [CrossRef]

46. Ju, X.T.; Gu, B.J.; Wu, Y.Y.; Galloway, J.N. Reducing China's fertilizer use by increasing farm size. Glob. Environ. Chang. 2016, 41, 26-32. [CrossRef]

47. Rahman, S. Agroecological, climatic, land elevation and socio-economic determinants of pesticide use at the farm level in Bangladesh. Agric. Ecosyst. Environ. 2015, 212, 187-197. [CrossRef]

48. Wang, Y.; Zhu, Y.C.; Zhang, S.X.; Wang, Y.Q. What could promote farmers to replace chemical fertilizers with organic fertilizers? J. Clean. Prod. 2018, 199, 882-890. [CrossRef]

49. Lu, H.; Xie, H.L.; He, Y.F.; Wu, Z.L.; Zhang, X.M. Assessing the impacts of land fragmentation and plot size on yields and costs: A translog production model and cost function approach. Agric. Syst. 2018, 161, 81-88. [CrossRef]

50. Rabbi, F.; Ahamad, R.; Ali, S.; Chandio, A.A.; Ahmad, W.; Ilyas, A.; Din, I.U. Determinants of commercialization and its impact on the welfare of smallholder rice farmers by using Heckman's two-stage approach. J. Saudi Soc. Agric. Sci. 2019, 18, 224-233.

51. Lu, H.; Xie, H.L. Impact of changes in labor resources and transfers of land use rights on agricultural non-point source pollution in Jiangsu Province, China. J. Environ. Manag. 2018, 207, 134-140. [CrossRef] [PubMed]

52. Gbénou-Sissinto, E.; Adegbola, Y.P.; Biaou, G.; Zossou, R.C. Farmers' Willingness to Pay for New Storage Technologies for Maize in Northern and Central Benin. Sustainability 2018, 10, 2925. [CrossRef]

53. Sklenicka, P.; Janovska, V.; Salek, M.; Vlasak, J.; Molnarova, K. The Farmland Rental Paradox: Extreme land ownership fragmentation as a new form of land degradation. Land Use Policy 2014, 38, 587-593. [CrossRef]

54. Mottaleb, K.A. Perception and adoption of a new agricultural technology: Evidence from a developing country. Technol. Soc. 2018, 55, 126-135. [CrossRef] [PubMed]

55. Yigezu, Y.A.; Mugera, A.; El-Shater, T.; Aw-Hassan, A.; Piggin, C.; Haddad, A.; Khalil, Y.; Loss, S. Enhancing adoption of agricultural technologies requiring high initial investment among smallholders. Technol. Forecast. Soc. 2018, 134, 199-206. [CrossRef]

(C) 2019 by the authors. Licensee MDPI, Basel, Switzerland. This article is an open access article distributed under the terms and conditions of the Creative Commons Attribution (CC BY) license (http://creativecommons.org/licenses/by/4.0/). 